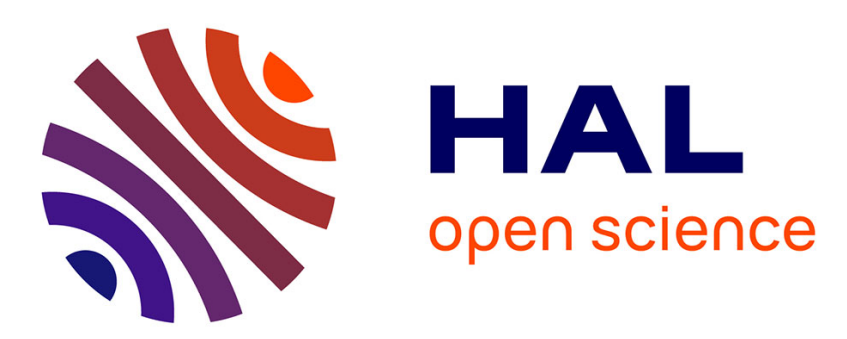

\title{
Time-resolved XAS and XRD studies on the solid-state ion exchange of platinum into zeolite $\mathrm{Y}$
}

\author{
U. Hatje, T. Ressler, S. Petersen, H. Förster
}

\section{To cite this version:}

U. Hatje, T. Ressler, S. Petersen, H. Förster. Time-resolved XAS and XRD studies on the solidstate ion exchange of platinum into zeolite Y. Journal de Physique IV Proceedings, 1994, 04 (C9), pp.C9-141-C9-144. 10.1051/jp4:1994921 . jpa-00253482

\section{HAL Id: jpa-00253482 https://hal.science/jpa-00253482}

Submitted on 1 Jan 1994

HAL is a multi-disciplinary open access archive for the deposit and dissemination of scientific research documents, whether they are published or not. The documents may come from teaching and research institutions in France or abroad, or from public or private research centers.
L'archive ouverte pluridisciplinaire HAL, est destinée au dépôt et à la diffusion de documents scientifiques de niveau recherche, publiés ou non, émanant des établissements d'enseignement et de recherche français ou étrangers, des laboratoires publics ou privés. 


\title{
Time-resolved XAS and XRD studies on the solid-state ion exchange of platinum into zeolite $Y$
}

\author{
U. Hatje, T. Ressler, S. Petersen and H. Förster
}

Institute of Physical Chemistry, University of Hamburg, Bundesstr. 45, 20146 Hamburg, Germany

\begin{abstract}
The course of solid-state ion exchange of $\mathrm{NH}_{4} \mathrm{Y}$ zeolite with platinum oxide, chloride and bromide was monitored by TPR, XRD and - for the first time - by DEXAFS. In the absence of air $\mathrm{PtO}_{2}$ and $\mathrm{PtCl}_{2}$ are reduced at about $300^{\circ} \mathrm{C}$ to oxidation state zero by ammonia from the zeolite under formation of highly dispersed platinum clusters. In the presence of air this reduction is inhibited and the chlorine neighbour of Pt is replaced by oxygen. Hydrogen treatment resulted in a reduction to a formal oxidation number lower than zero which might be tentatively explained either by formation of a hydride phase or by quantum-size effects. In situ XRD experiments prove the migration of the salt components into the channels of the zeolite, although partial reaction at the outer surface cannot be excluded. In the case of platinum bromide, after reaction bromine cannot be completely removed from the sample, even at $500^{\circ} \mathrm{C}$.
\end{abstract}

\section{INTRODUCTION}

The preparation of highly dispersed metal particles for catalytical and other applications is one of the major goals of recent research [1]. One way for the formation of so-called nanoclusters is to enable their growth inside a zeolite matrix under the spatial constraints of the host. This is normally done by conventional ion exchange in aqueous solution followed by reduction. A new route to ion exchange is offered by solid-state reactions of ammonium or hydrogen forms of zeolites with metal oxides or halides. Monitoring theses processes by XRD, TPR and - for the first time - by XAS is the topic of this article.

\section{EXPERIMENTAL}

Intimate mixtures of $\mathrm{PtO}_{2}, \mathrm{PtCl}_{2}$ and $\mathrm{PtBr}_{2}$ with $\mathrm{NH}_{4} \mathrm{Y}$ zeolite were pressed into circular self-supporting specimens applying a pressure of 200 bar. Half of the wafer so formed was introduced into the XAS flowcell (see Fig. 1) together with the other half of a pure $\mathrm{NaY}$ wafer, used for the $\mathrm{I}_{0}$ measurement. The samples were placed at the focus of the polychromatic X-ray beam $(300 \mu \mathrm{m} \times 300 \mu \mathrm{m})$ and heated to $500^{\circ} \mathrm{C}$ at a rate of $15^{\circ} \mathrm{C}$ per minute in a flow of helium or air $\left(40 \mathrm{ml}\right.$ per minute) using a Variotemp ${ }^{\mathrm{TM}}$ temperature controller attached to a PC for data acquisition. During this treatment Dispersive Extended X-ray $\underline{\text { Absorp- }}$ tion Fine Structure (DEXAFS) spectra were recorded in a sequence of 10 seconds at the Pt $\mathrm{L}_{\pi I}$-edge $(11.564 \mathrm{keV})$ and, in case of $\mathrm{PtBr}_{2}$, at the $\mathrm{Br} \mathrm{K}$-edge $(13.474 \mathrm{keV})$ with a spectral range of $800 \mathrm{eV}$ and a resolution of $1 \mathrm{eV}$ [2]. Due to the high photon flux each recorded spectrum could be averaged over 100 samplings in order to receive high quality data. The dark signal of the detector, the $\mathrm{I}_{0}$ signal and a metal foil were measured before and after the reaction for each experiment. The conversion from photodiodes to the photon energy was performed by applying a second-order polynominal on the data. The coefficients of 
the polynomial were obtained from a computer-supported comparison of the metal foil spectrum with a platinum reference spectrum.

The spectra were background corrected by a first-order polynominal and normalised to an edge jump of one (except for the bromine experiment). The $\mathrm{E}_{0}$ value was chosen as the first inflection point of the absorption edge. The atomic absorption was calculated by fitting a fifth-order polynominal to the kweighted data. After that the extracted $\chi(k)^{*} k^{2}$ was multiplied by a Kaiser-Bessel window and Fourier transformed (FT) to obtain the radial distribution function.

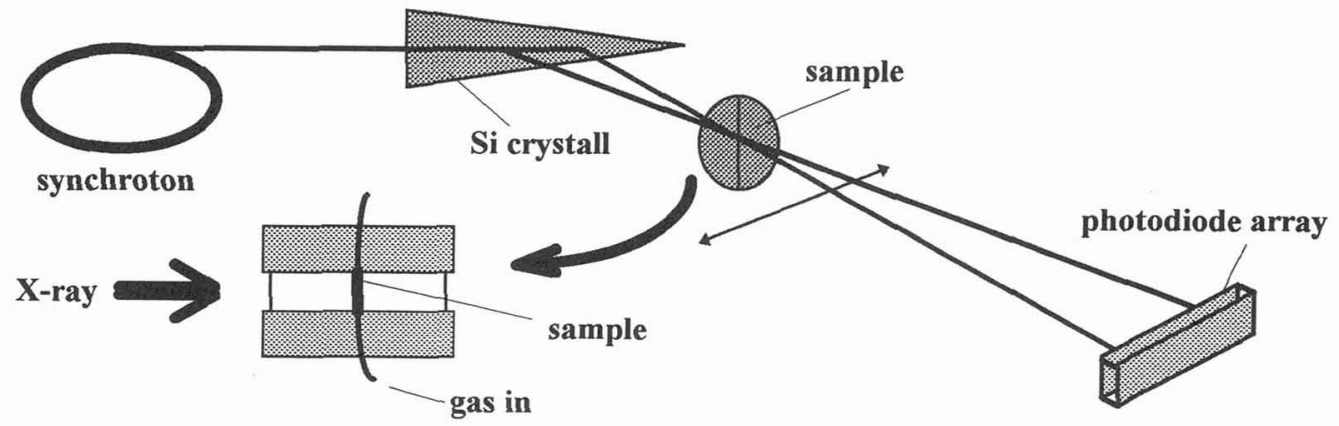

Fig. 1: DEXAFS set-up at Beamline X 1.2/HASYLAB, Hamburg.

The in situ XRD measurements were performed using a standard XRD two-circle setup and a copper $\mathrm{K}_{\alpha}$ $X$-ray source. The sample was placed on a platinum wire $(100 \mathrm{~mm} \times 10 \mathrm{~mm} \times 1 \mathrm{~mm})$ and could be heated by an electrical current flowing through the wire, controlled by a commercial temperature controller.

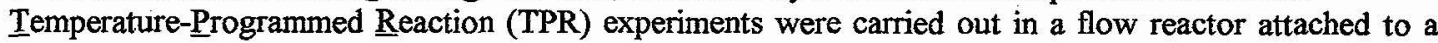
mass spectrometer.

\section{RESULTS AND DISCUSSION}

The XANES of the $\mathrm{Pt} \mathrm{L}_{\mathrm{II}}$-edge during the reaction of $\mathrm{PtO}_{2}$ with $\mathrm{NH}_{4} \mathrm{Y}$ in helium is shown in Fig. 2. The decrease of the white line at the $\mathrm{Pt} \mathrm{L}_{\mathrm{II}}$-edge $\left(2 \mathrm{p}_{3 / 2} \rightarrow 5 \mathrm{~d}_{5 / 2}\right)$ is due to the reduction of platinum to oxidation number zero. This is indicated also by a shift of the edge to lower energies, starting at about $250^{\circ} \mathrm{C}$. The Fourier transform of the EXAFS $(11.65 \mathrm{keV}$ to $12.1 \mathrm{keV})$ from the spectra shown in Fig. 2 reveals a decrease of the $\mathrm{Pt}-\mathrm{O}$ shell at $1.5 \AA$ starting at $250^{\circ} \mathrm{C}$ and, above $300^{\circ} \mathrm{C}$, the development of a PtPt shell at $2.2 \AA$ (see Fig. 3). From TPR we know that at this temperature platinum is reduced by ammonia from the zeolite under formation of nitrogen and water. As this reaction gives rise to a sharp nitrogen peak

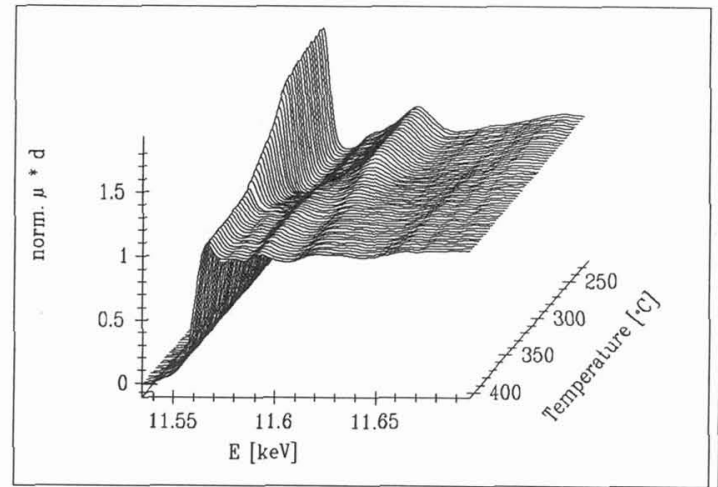

Fig. 2: XANES of the $\mathrm{Pt} \mathrm{L}_{\mathrm{II}}$-edge during the $\mathrm{PtNH}_{4} \mathrm{Y} / \mathrm{PtO}_{2}$ solid-state reaction in $\mathrm{He}$.

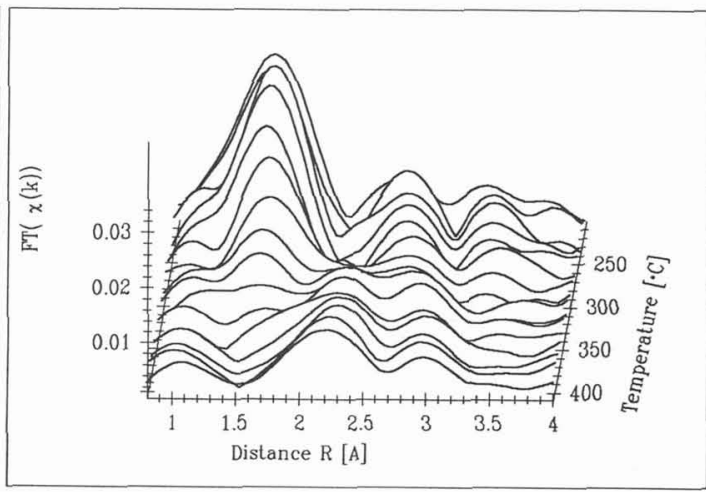

Fig. 3: FT[ $\chi(\mathrm{k})]$ of the EXAFS (11.65 keV to $12.1 \mathrm{keV}$ ) from the spectra shown in Fig. 2. 
(half-width of about one minute) in contrast to that of ammonia desorption from the zeolite, which is far broader (10 or more minutes), this might be an indication that the platinum oxide or chloride migrates into the zeolite before the reaction takes place.

The reaction of $\mathrm{PtCl}_{2}$ with $\mathrm{NH}_{4} \mathrm{Y}$ in helium led to similar results: The white line at the $\mathrm{Pt}_{\mathrm{III}}$-edge decreases during reaction proving the reduction of platinum, although, due to the higher occupation of the platinum $5 \mathrm{~d}_{5 / 2}$ orbital by chlorine, its initial height is lower compared to $\mathrm{PtO}_{2}$ (see Fig. 4). In this case the Fourier tranform of the EXAFS (Fig. 5) reveals a decrease of the $\mathrm{Pt}-\mathrm{Cl}$ shell $\left(1.75 \AA\right.$ ) at $280^{\circ} \mathrm{C}$ followed by the development of a Pt-Pt shell $(2.2 \AA)$ at $320^{\circ} \mathrm{C}$. Again, TPR experiments indicate the reduction of the platinum by the ammonia from the zeolite by the formation of a sharp nitrogen peak.

Concluding these results the reaction of the $\mathrm{PtO}_{2} / \mathrm{NH}_{4} \mathrm{Y}$ as well as of the $\mathrm{PtCl}_{2} / \mathrm{NH}_{4} \mathrm{Y}$ mixture in helium leads to metallic platinum clusters. Although the TPR experiments sustain the expectation that platinum oxide or chloride migrate into the zeolite before the reaction takes place, the reaction of at least part of the salts outside the zeolite cannot be excluded.

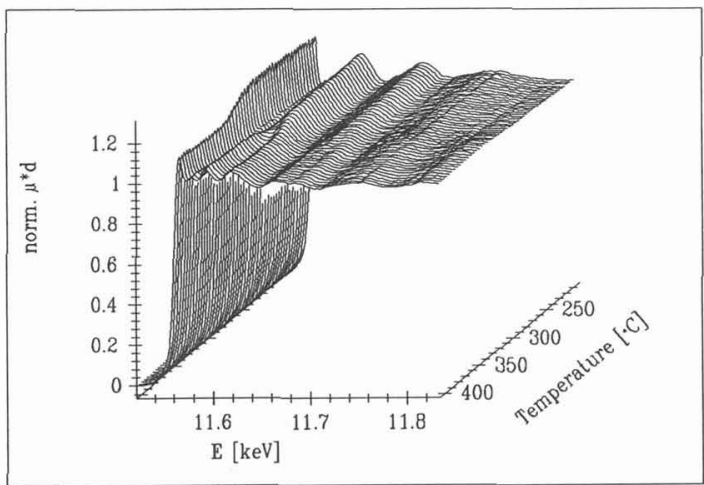

Fig. 4: XANES of the Pt $\mathrm{L}_{\text {III-edge during the }}$ $\mathrm{PtNH}_{4} \mathrm{Y} / \mathrm{PtCl}_{2}$ solid-state reaction in $\mathrm{He}$.

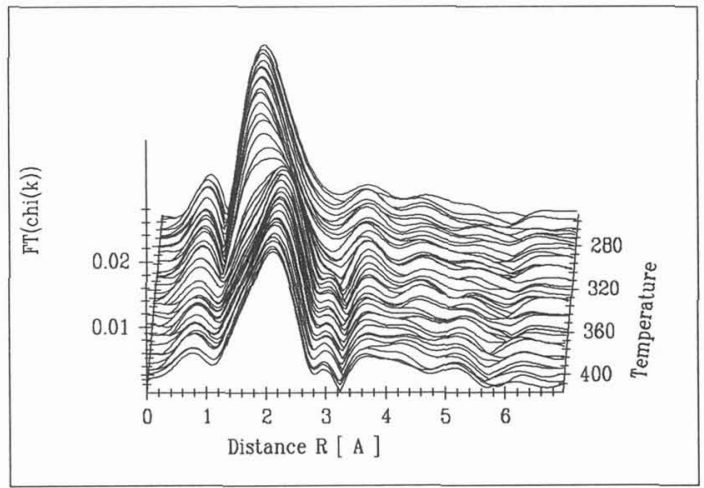

Fig. 5: FT $\chi \chi(k)]$ of the EXAFS (11.65 keV to 12.1 keV) from the spectra shown in Fig. 4.

When carrying out the reaction of $\mathrm{PtO}_{2}$ with $\mathrm{NH}_{4} \mathrm{Y}$ in air only minor changes can be observed in both the XANES and EXAFS of $\mathrm{PtO}_{2}$ at the Pt $\mathrm{L}_{\mathrm{II}}$-edge. Even after subsequent TPR in helium almost the same spectrum is obtained (Fig. 6). This means that there is no reduction of the platinum by ammonia from the zeolite in presence of oxygen.

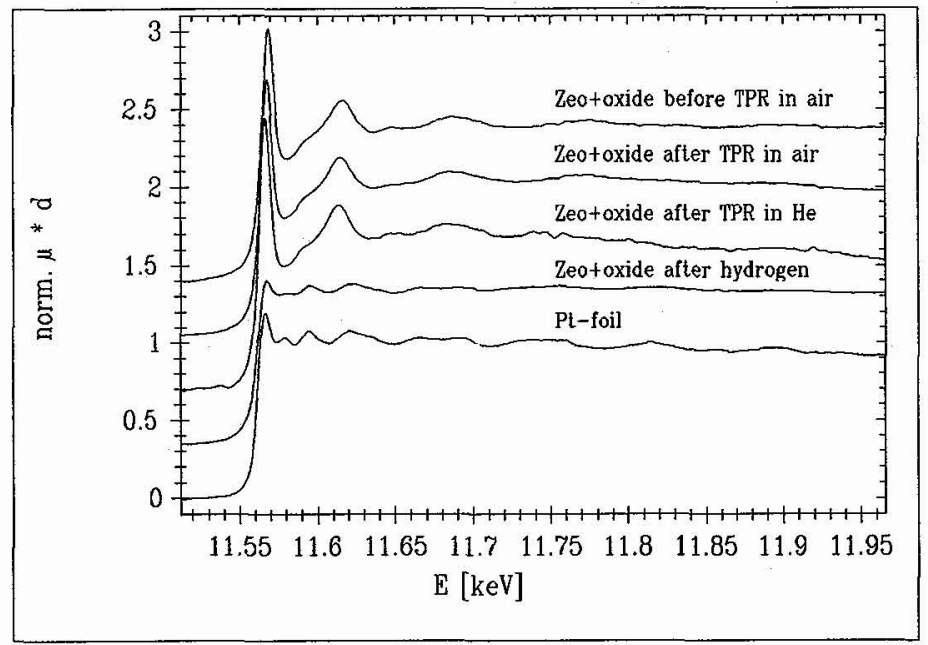

Fig. 6: XANES and EXAFS of $\mathrm{PtO}_{2} / \mathrm{NH}_{4} \mathrm{Y}$ mixture before and after reaction in air, after subsequent reaction in helium and after subsequent hydrogen admission at room temperature. A platinum foil is shown for reference. 
With hydrogen, however, it is possible to reduce the platinum at room temperature not only to oxidation state zero, but to a formal negative oxidation number: After $\mathrm{H}_{2}$ admission the edge of the spectrum obtained is shifted by about $0.5 \mathrm{eV}$ to lower energies and the white line is actually of lower intensity compared with that of a platinum foil which might be tentatively explained either by formation of a hydride $\alpha$-phase or by quantum-size effects. The latter is currently being discussed for very small metal clusters $[3,4]$ which have neither atomic nor bulk material properties and which therefore are very interesting in the study of quantum-size effects.

Again, the reaction of $\mathrm{PtCl}_{2}$ with $\mathrm{NH}_{4} \mathrm{Y}$ in air is somewhat similar: Neither reduction of the platinum nor growing of clusters can be observed. Starting at $280^{\circ} \mathrm{C}$ the $\mathrm{Pt}-\mathrm{Cl}$ shell at $1.75 \AA$ is replaced by an Pt-O shell at slightly lower distances $(1.5 \AA)$. In situ XRD measurements show the dissappearence of the platinum chloride reflections $\left(2 \theta=12.85^{\circ}\right.$ and $\left.13.5^{\circ}\right)$ starting at $250^{\circ} \mathrm{C}$ and an increase of the [111] and [220] reflections $\left(2 \theta=6.2^{\circ}\right.$ and $\left.10.2^{\circ}\right)$ of zeolite $\mathrm{NH}_{4} \mathrm{Y}$ (Fig. 7). As these reflections result mainly from cations on their positions in the zeolite cages this directly proves the migration of platinum particles onto these sites.

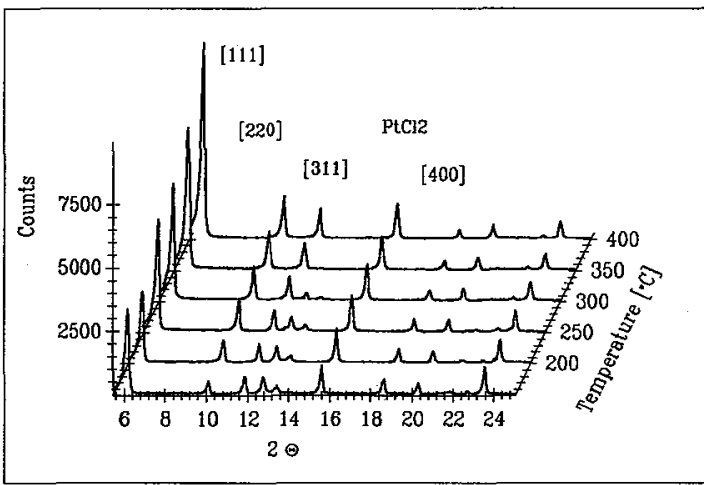

Fig. 7: In situ XRD diagrams of $\mathrm{PtCl}_{2} / \mathrm{NH}_{4} \mathrm{Y}$ mixture during reaction in air.

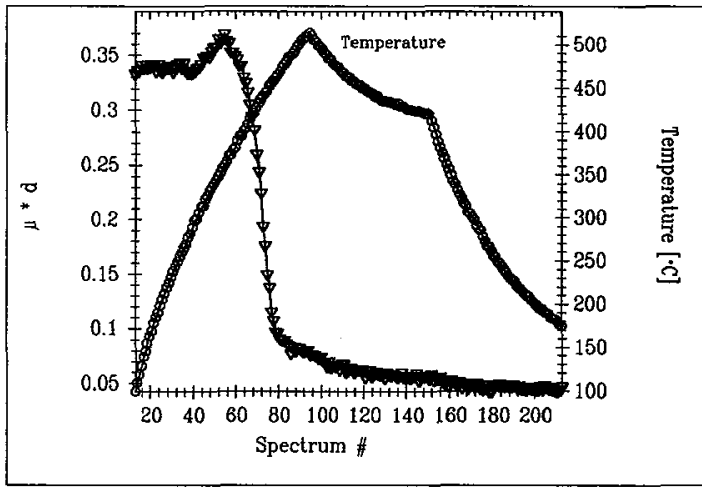

Fig. 8: Bromine loss during $\mathrm{PtBr}_{2} / \mathrm{NH}_{4} \mathrm{Y}$ reaction derived from the $\mu * \mathrm{~d}$ of the sample.

In order to find out something about the role which the halogen plays in this solid-state reaction, a mixture of $\mathrm{PtBr}_{2}$ with $\mathrm{NH}_{4} \mathrm{Y}$ has been studied at the $\mathrm{Br} \mathrm{K}$-edge. Fig. 8 shows the bromine loss of $\mathrm{PtBr}_{2} / \mathrm{NH}_{4} \mathrm{Y}$ during reaction. Raising the temperature above $350^{\circ} \mathrm{C}$ the bromine concentration increases due to the development of $\mathrm{HBr}$ and then decreases to about 15 percent of its initial value. Even at temperatures as high as $500^{\circ} \mathrm{C}$ bromine cannot be completely removed. After reaction part of the bromine was found in the NaY wafer used for the $I_{0}$ measurement.

\section{CONCLUSIONS}

$\mathrm{PtO}_{2}$ as well as $\mathrm{PtCl}_{2}$ react with $\mathrm{NH}_{4} \mathrm{Y}$ zeolite in the solid state. In helium atmosphere the platinum of both $\mathrm{PtO}_{2}$ and $\mathrm{PtCl}_{2}$ is reduced to oxidation state zero at about $300^{\circ} \mathrm{C}$ by the ammonia from the zeolite. In presence of oxygen this reduction is inhibited, but in case of $\mathrm{PtCl}_{2}$ the chlorine as the next neighbour of platinum is replaced by oxygen at about $300^{\circ} \mathrm{C}$. In situ XRD measurements proved the migration of platinum into the zeolite on cation sites during the $\mathrm{PtCl}_{2} / \mathrm{NH}_{4} \mathrm{Y}$ reaction in air. From experiments with $\mathrm{PtBr}_{2}$ it can be concluded that after reaction the bromine partly remains inside the zeolite.

\section{REFERENCES}

[1] G.A. Ozin and C.Gil, Chem. Rev., 89 (1989) 1749-1764.

[2] M. Hagelstein, PhD Thesis, Kiel, 1991.

[3] A.N. Mansour, J.W. Cook, Jr., and D.E. Sayers, J. Phys. Chem., 88 (1984) 2330-2334

[4] G. Schulz-Ekloff, private communication. 